\title{
Analysing the Interplay Between Institutional-Based and Workplace Learning
}

Dinavence Arinaitwe and Arne Ronny Sannerud

\section{Abstract}

Learning and working are two significant social networks in preparing individuals for future life. An understanding of learning in the workplace can inform how we organise institutional learning in order to produce competent and relevant vocational education and training (VET) graduates for the world of work. In this paper, we explored the current collaborative activities in the masters in vocational pedagogy (MVP) study program at Kyambogo University in Uganda and their linkage with workplaces. Two research questions are posed. (1) What collaborative activities are in the MVP program that allows for learning in vocational teacher training institutions (VTIs) and workplaces? 2) How is knowledge constructed amongst the participating actors? We investigated the questions through in-depth, semi-structured interviews with purposively sampled participants. An analysis of the documents from the MVP project, including program reports, collaborating stakeholders meeting minutes, and students' theses were done. The findings revealed that field expeditions and action research (AR) projects are the principal activities incorporated in the MVP program to support the back and forth learning from workplaces. Through interactions and sharing practices, these activities promoted learning by solving problems encountered at work and by doing real-life tasks.

Keywords: field expeditions, action research projects, collaborative activities, vocational teacher training institutions, activity systems. 


\section{Introduction}

Vocational education and training (VET) prepare individuals to meet job requirements in workplaces (UNESCO, 2017; Ayonmike, 2016). Kato and Nsibambi (2017) observed that this goal is attained by synchronising training in institutions and work requirements in order to align teaching programs with workplace expectations. However, how can this synchronism be achieved? Spootl (2000, cited in Ridzwan et al., 2015, p.61) suggests a need to benchmark the skills required by industries in achieving the synchronisation in which training institutions can successfully meet the demands of workplaces. Fenwick (2001) observed that understanding how learning happens in the workplace informs how we organise institutional learning at all levels. One possible avenue for benchmarking the skills required by industries is through institution-workplace collaboration (IWC), where several research studies have shown the benefits of this collaboration (Hadidi \& Kirby, 2017; Ankrah \& Al-Tabbaa, 2015; Flynn, Pillay \& Watters, 2016). These benefits include increasing and updating the practical vocational expertise of vocational teachers (Ridzwan et al., 2015) as well as facilitating the sharing of expertise across physical, social, and cultural boundaries in developing and delivering VET programs of study (Reid, 2015). IWC is also advantageous in enabling VET graduates to acquire practical skills, a professional attitude and a gradual understanding of work life (UNESCO UNEVOC, 2012). Lucas (2014) suggests that not only do vocational teacher educators need to be experts in their subject, but they should also have practical and up-to-date vocational expertise relevant to the workplace; attainable through IWC.

Although institutional-based and workplace learning appears well researched, this is mainly in developed countries (Jonasson, 2014; Nisbet, Lincoln \& Dunn, 2013; Davids, Bossche, Gijbels \& Garrido, 2017; Mulcahy, 2011; Flynn, Pillay \& Watters, 2016).

There is little published data on the same topic in transitioning economies and developing countries, particularly for Uganda (Hadidi \& Kirby, 2017). The lack of data reflects a need to study IWC for Uganda's VET system in order to understand how it contributes to the production of skilled workers. Promoting IWC is one of the motives behind the MVP program offered at Kyambogo University in Uganda, which is the focus of this paper.

This paper critically examines the current collaborative activities in the MVP study program that promotes learning through collaboration between VTIs and workplaces in Uganda. Two research questions guided the study. (1)What collaborative activities are in the MVP study program that allows for learning between VTIs and workplaces? (2) How is knowledge 
constructed amongst the participating actors? The term 'actors' is employed to refer to all persons engaged in implementing the collaborative activities of the MVP program, the VTIs, and the workplaces.

\section{Masters in Vocational Pedagogy (MVP) Program at Kyambogo University}

The master's degree in vocational pedagogy is a two-year fulltime course; the general objective is to offer content covering pedagogical principles, practices, and issues related to VET. MVP graduates should demonstrate functional knowledge, skills, and values for all types of work that are essential for development in VET and other social worlds (Kyambogo University, 2009). The focus is on linking knowledge with the world of work through establishing contacts and cooperation with stakeholders in schools, professional bodies, enterprises, and trade organisations (Kyambogo University, 2013). These efforts have led to several collaborative activities to be initiated.

Vocational pedagogy is a field of knowledge-oriented towards occupations and professions (Mjelde, 2006; Lucas, 2014).

Vocational pedagogy is a learner-centred approach to teaching and learning in which the relationship between the student and the task is central, and the work activity itself is the rotation point for learning (Mjelde, 2006; 2017). The MVP program's work method conforms to the workshop learning model, which encourages practical learning (Mjelde \& Daly, 2012). Furthermore, experience-based learning activities, problem-oriented tasks, learning by doing, as well as participation in group and teamwork provide the direction for organising the program (Kyambogo University, 2009). Learning under the MVP takes place both in educational institutions and workplaces in order to integrate general knowledge, theory, and practical training in light of the needs and demands of the labour market (Mjelde, 2017). However, in Uganda, the concept of vocational pedagogy is a new phenomenon whose roots trace back from the inception of the MVP. VET has been, though to a great extent influenced by the British system that is predominantly teacher centred (Okello, 2009; Ssekamwa, 1997), which is a source of tension in introducing vocational pedagogy. 


\section{Institutional-Workplace Collaboration in Uganda: Policies and Practices}

In Uganda, IWC is addressed by several reforms and strategies. The Business Technical Vocational Education and Training (BTVET) strategic plan 2012/13 - 2021/2 emphasises a paradigm shift from school-based training to the flexible workplace-oriented environment and government funded and controlled to public/private partnership (Ministry of Education and Sports [MoES], 2012). Furthermore, the BTVET Act (Uganda, 2008, pp. 5-6) also focuses on establishing private-public partnerships, promoting training with production concepts, and promoting the types of BTVET qualifications in which people train by labour market requirements. Mandated by the policies above, the private sector engaged in skills training for VET trainees through participation in internship programs, curriculum development, and teaching and learning processes.

However, the lack of comprehensive, multi-sectoral government policies and consistent programs to encourage the private sector to invest in skills development (Ministry of Education \&Sports [MoES], 2014; Kalanda, 2012) constrain private-public partnerships. In this regard, Kato and Nsibambi (2017) made a case for a national policy to guide workplace learning activities.

Collaborations between training institutions and workplaces in the VET system have existed globally for a long time (Kitagaana, 2018). In Uganda, the most common collaborative activities are internship programs (Kalanda, 2012) and school placements (Otaala, Maani \& Bakaira, 2013). Other collaborative activities are mainly informal and short term, and they include project works, field visits, seminars, workshops, meetings, and conferences. However, Oyo (2011) observed low regard for these IWCs, specifically internships, for which, students had trouble securing placements, and if they did, few workplaces had training officers to provide guidance.

\section{Conceptualising Institution and Workplace Learning}

From the expansive theory perspective (Engestrom, 2001; 2016), learning refers to the ability of actors to jointly participate in executing activities in order to create new knowledge and practices from the emerging activities. Learning takes various forms: formal, informal or incidental (Marsick \&Watikins, 2015) and non-formal. Formal learning takes place in schools, while informal, incidental, and non-formal learning takes place mostly in the 
workplace. Eraut (2000 as cited in Nisbet, et al., 2013, p.469), generally characterised formal learning by prescribed learning frames, organised learning packages, and the award of a qualification.

In workplace learning, however, skills are upgraded, and knowledge is acquired while doing work (Cacciattolo, 2015). Workplace learning is further characterised by unintentional, unstructured and uncertified (Mackenzie \& Polvere, 2009); a teacher is usually absent (Eraut, 2004). Although Eraut (2004) acknowledges the absence of a teacher in informal learning, he recognises the significance of a mentor; who is an experienced adviser, in this kind of learning.

In the context of this paper, IWC refers to the interaction between any parts of the educational system and workplace to promote learning through collaboration, encourage knowledge and technology exchange.

\section{Theoretical Framework}

\section{Activity Theory}

This study focuses on examining the current collaborative activities in the MVP study program that promote learning through collaboration between VTIs and workplaces in Uganda. To gain insight into the study, the Cultural-historical Activity Theory (CHAT), particularly the third generation, was employed (Engestrom, 1987; 2001; 2005; 2016). The third generation is concerned with conceptual tools to understand dialogue, multiple perspectives and the networks of interacting activity systems (Engestrom, 2001). From this perspective, CHAT focuses on complex interrelations between the subject, the object and a community of two or more activity systems (Engestrom, 2001). For that matter, we have employed CHAT in analysing three interacting activity systems: activity system 1 - the MVP program at Kyambogo University; activity system 2-workplaces; organisations and industries; and activity system 3-VTIs. The following figures $1 \mathrm{a}-\mathrm{c}$ show the each of the three activity systems and figure $1 \mathrm{~d}$ explains the interaction between the three systems. 
Mediating artefacts: Curriculum, Research tools,

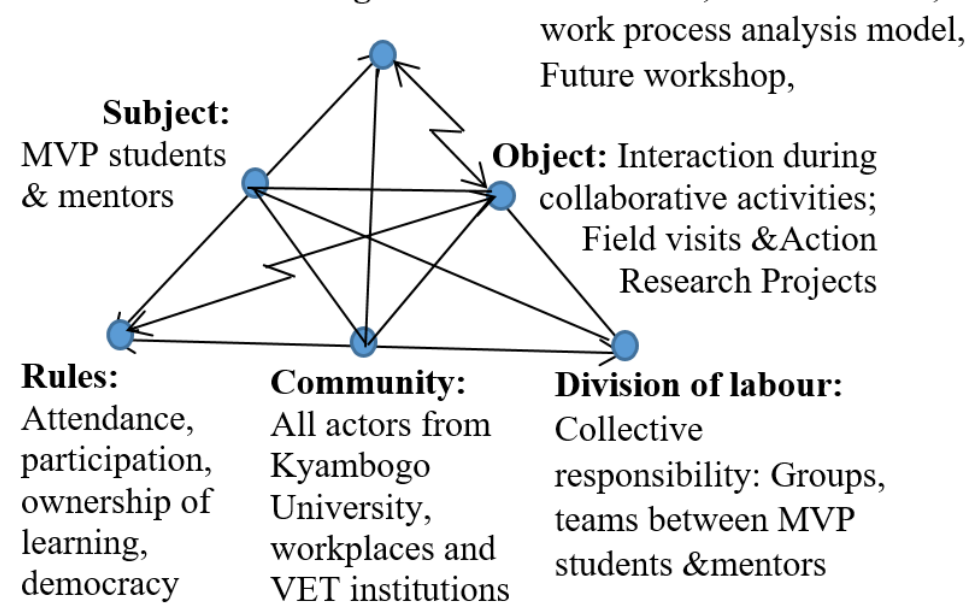

\section{Figure 1a:}

Activity System 1, the MVP Program

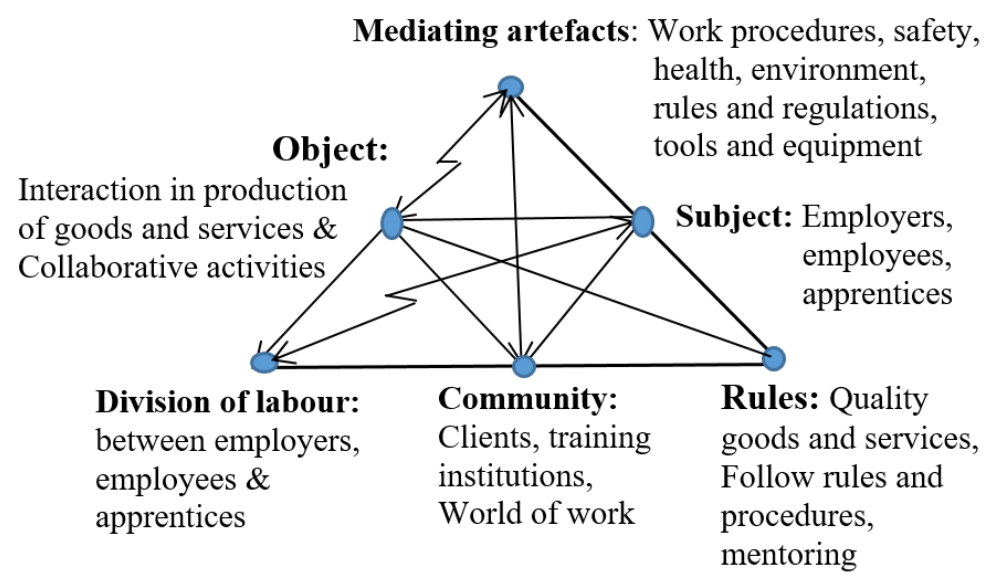

\section{Figure 1b:}

Activity system 2, Workplaces

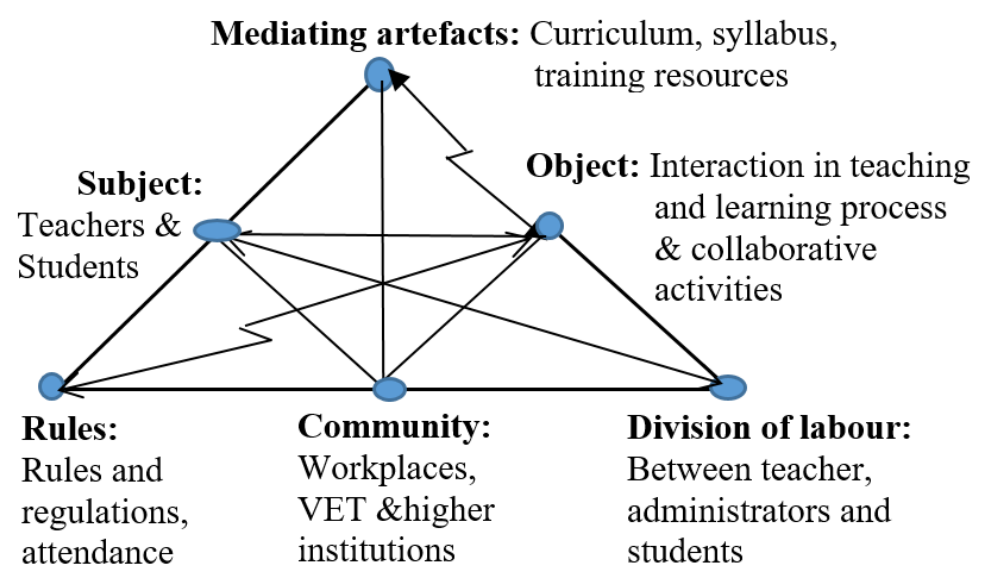

\section{Figure 1c:}

Activity system 3, Vocational teacher training institutions VTIs 


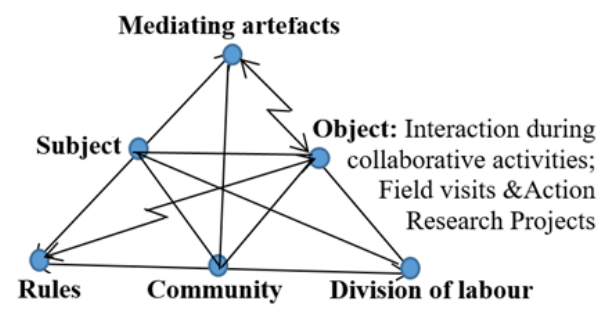

Activity system 3: Vocational teacher training institutions VTIs

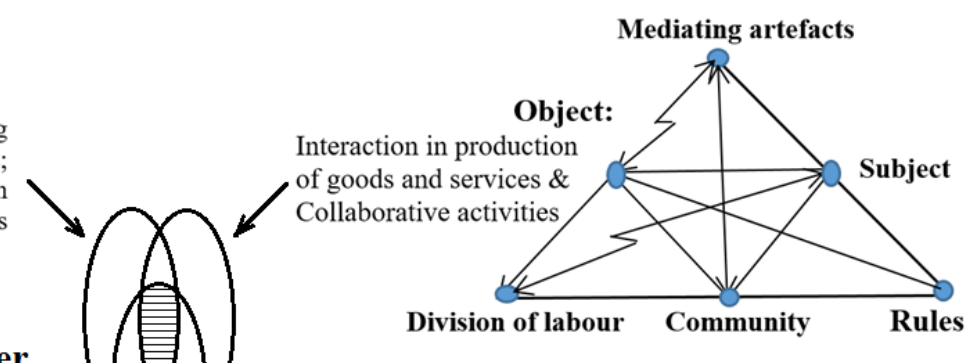

Activity system 2: Workplaces

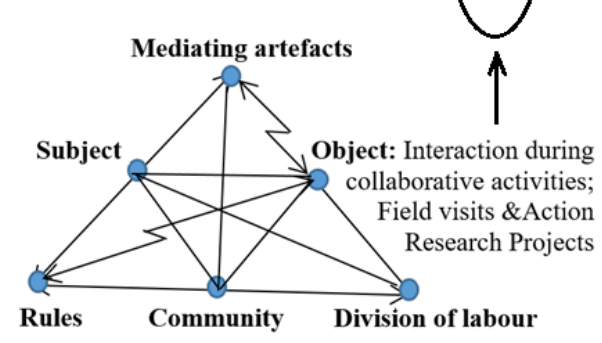

Activity system 1: MVP program

\section{Figure 1d:}

Using CHAT to analyse the three interacting activity systems in collaborative activities. Outcomes from the interaction between the three activity systems are new learning, improvement in practice and production, and patterns of collaboration.

In the first principle of the third generation of CHAT, a collective, artefact-mediated and object-oriented activity system is the prime unit of analysis seen in relation with a network of other activity systems (Engestrom, 2001). From figure 1, the object of analysis is the interaction between the actors of the three activity systems during collaborative activities. These interactions are avenues for actors' participation and learning in collaborative activities. Learning through participation is supported by Sannino, Daniels, and Guteirrez's (2009), who argue that learning is fundamentally rooted in participation in human activities oriented toward objects. Furthermore, the first principle states that the goal-directed individual and group actions are relatively independent but subordinate units of analysis.

However, these subordinate units of analysis are understandable when interpreted against the background of entire activity systems. The activity systems realise and reproduce themselves by generating actions and operations (Engestrom, 2001, p.136). Relating to figure 1 above, the subjects of the three systems interact and act individually or in groups on collaborative activities. They are aided by the mediating artefact tools as well as the signs; the systems influence one another and the entire system. Analysing these interactions within and across the activity systems informs the study on the ways the artefacts mediate how the actors of the three systems think, act and interact with one another and with objects in their environment. 
Analysing these interactions facilitates an understanding of knowledge generation among the actors and how to resolve the contradictions arising within the systems.

The second principle of CHAT is concerned with the plurality of voices in the activity system; it is a community of multiple points of view, traditions, and interests (Engestrom, 2001). Each of the three systems in their setting targets different goals and objectives, although participation in collaborative activities is a unifying factor. Furthermore, principle two asserts that the division of labour in the activity system creates different positions for the participants with their diverse histories. Also, the activity system carries multiple layers and strands of history engraved in its artefacts, rules, and conventions which become a source of trouble as well as innovation and demand action, translation and negotiation (Engestrom, 2001, p.136). The actors divide collaborative activities amongst themselves; execute them under the guidance of a set of rules and procedures by each system in its diverse cultural and environmental settings. The differences in culture and environments influence how the actors interpret and make sense of the artefact tools and signs, which is necessary to implement collaborative activities. The differences in the actors' cultures and disciplines, and the weak instruments for collaboration become a source of contradictions within the activity systems (Engestrom, 2005).

However, Engestrom $(2001 ; 2005)$ argues that the internal contradictions in an activity system are the driving force of change and development. For example, making learning more relevant to workplace needs in VTIs was a major reason for initiating collaborative activities in the MVP program, even though the contradictions in the systems, at times, constrain the activeness of the actors in implementing these activities.

\section{Expansive Learning}

Engestrom $(2001 ; 2005)$ employed the concepts of expansive learning to illustrate the network of interacting systems, which is the focus of this study. From this perspective, learning relies on the metaphor of expansion, in which the learners construct a new object and concept for their collective activity and implement it in practice (Engestrom, 2016).

Engestrom (2001) further argues that expansive learning activity produces culturally new patterns of activity, wherein its relationship to work produces new forms of work activity. The concept of expansive learning is vital in understanding how collaborative activities, particularly action research projects by the MVP program, are initiated and implemented to cause a change in teaching and learning processes, and work processes in both VTIs and 
workplaces. Another significant aspect of expansive learning is the notion of the double bind introduced by Bateson (1972, as cited in Engestrom, 2001, p.138). The notion of double bind expresses the third level of learning, which Bateson describes as a collective endeavour. Under this notion, an individual or a group of people radically question an existing practice. In so doing, they collaborate to model and develop new practices. All of the members of the collective activity system jointly and collaboratively analyse and implement a new model of the activity (Engestrom, 1987; 2016; Engestrom \& Sannino, 2010). The notion of the double bind is reflected in AR projects, where actors collaborate to solve challenging situations in their teaching and work practices.

\section{Methodology}

A case study embedded with multiple units of analysis (Yin, 2014) was the preferred design in tackling the research questions. This research design allows for building an in-depth and contextual understanding of the units under investigation. Collaborative activities and the actors' knowledge generation from these activities were the units of analysis in the study. The MVP study program offered at Kyambogo University was the main site of the study, while the two VTIs and three workplaces are the embedded sites of study. All of the sites sampled from the central and eastern regions of Uganda. The sampled institutions and workplaces have participated in MVP collaborative activities for at least three years. The research process started in 2016, although the data collection was between January and June 2017. Patton (1990; 2002), and Tavakol and Sandars (2014) support the use of purposive sampling in accessing respondents with in-depth knowledge about collaborative activities. We used this approach in selecting 28 participants for the study in the following categories: 13 participants within the MVP program at Kyambogo University (mentors, students, Action research- AR project supervisors and project administrators); 12 participants (administrators, teachers, and students) from the 2 sampled VTIs that implemented AR projects, and 1manager/officer from each of the 3 workplaces (refer to Table 1). For anonymity, coded were accorded to all the participants' names.

The study utilized both primary and secondary sources to collect the necessary data. For instance, interview guides comprising both semi-structured and open-ended questions were used to conduct in-depth interviews of about 30 to 70 minutes with the majority of the participants; focus group interviews were held with VTI students. The interview questions focused on the following: activities in the MVP program related to workplace learning, the 
organisation and implementation of these activities, learning experiences, and knowledge generation in the collaborative activities.

Three sets of interview guided were used; categorised based on the respondents' roles, positions, and affiliation (refer to table 1). Mikkelsen (2005), and Kvale and Brinkmann (2015) suggest the use of semi-structured interviews to increase the comprehensiveness of the data and to make data collection more systematic for each respondent. Document analysis of MVP program documents; students' theses and Norwegian program for Capacity Development in Higher Education and Research Development (NORHED) -MVP project documents, reports, and collaborating stakeholders meeting minutes was done to complement interview data.

Table 1:

Details about the study participants

\begin{tabular}{|c|c|c|c|}
\hline $\begin{array}{l}\text { Type of data } \\
\text { source }\end{array}$ & $\begin{array}{l}\text { Duration } \\
\text { (Hours \& } \\
\text { minutes) }\end{array}$ & Kind of respondents & Remarks \\
\hline \multirow{3}{*}{$\begin{array}{l}\text { Interviews } \\
\text { and field } \\
\text { notes }\end{array}$} & $1: 30$ & $\begin{array}{l}2 \text { MVP students: } 1 \text { female (MVP } \\
\text { SF1) \& (MVP SM1) from cohort } 5\end{array}$ & $\begin{array}{l}\mathrm{SF}_{1}: 3 \text { years of teaching, } \\
\mathrm{SM}_{1} 23 \text { years of trade and } \\
\text { teaching }\end{array}$ \\
\hline & $1: 32$ & $\begin{array}{l}4 \text { Mentors for MVP: } \\
2 \text { senior mentors }-1 \text { male (MSM1) } \\
\& 1 \text { female (MSF1) }\end{array}$ & $\begin{array}{l}7 \text { and } 9 \text { years in mentoring } \\
\text { and over } 15 \text { years of } \\
\text { practice }\end{array}$ \\
\hline & $1: 23$ & $\begin{array}{l}2 \text { Junior mentors Male }\left(\mathrm{MJM}_{2}\right) \text { and } \\
\text { Female }\left(\mathrm{MJF}_{2}\right)\end{array}$ & $\begin{array}{l}4 \text { years of mentoring and } \\
\text { former MVP students }\end{array}$ \\
\hline \multirow[t]{2}{*}{$\begin{array}{l}\text { Interviews } \\
\text { and field } \\
\text { notes }\end{array}$} & $1: 38$ & $\begin{array}{l}\text { Action Research Project supervisors } \\
\text { (AS): } \\
1 \text { female (ASF1) for MVP SF1 and } \\
1 \text { male (ASN1) for MVP SM1 }\end{array}$ & $\begin{array}{l}\text { Both } 9 \text { years of mentoring } \\
\text { and over } 22 \text { years of } \\
\text { practice }\end{array}$ \\
\hline & $2: 37$ & $\begin{array}{l}\text { Norhed project administrators PA: } \\
\text { (administrative assistant, coordinator } \\
\& \text { head of department); } 1 \text { female } \\
\text { (PAF1) } 2 \text { males PAM1 and PAM2 }\end{array}$ & $\begin{array}{l}\text { Female less than } 5 \text { years of } \\
\text { work experiences, and male } \\
\text { over } 5 \text { years in } \\
\text { administration and } 15 \text { years } \\
\text { of practice }\end{array}$ \\
\hline $\begin{array}{l}\text { Interviews } \\
\text { and field } \\
\text { notes }\end{array}$ & $2 \mathrm{hrs}$ & $\begin{array}{l}2 \text { Vocational teacher training } \\
\text { institutions (VTIs): } \\
\text { VTI1 } 1 \text { male administrator AM1 } 2 \\
\text { male teachers: TM1 \& TM2 }\end{array}$ & $\begin{array}{l}\text { VTI1 } 9 \text { years collaborating } \\
\text { with MVP. } \\
\text { Both participants had over } \\
10 \text { years of work and } \\
\text { teaching experiences }\end{array}$ \\
\hline $\begin{array}{l}\text { Focus } \\
\text { group } \\
\text { interviews }\end{array}$ & 35 mins & $\begin{array}{l}3 \text { male students } \mathrm{SM}_{1} \text { of wood work } \\
\text { from } \mathrm{VT}_{1}\end{array}$ & $\begin{array}{l}\text { Had participate in action } \\
\text { research project by MVP } \\
\mathrm{SF}_{1}\end{array}$ \\
\hline
\end{tabular}




\begin{tabular}{|c|c|c|c|}
\hline $\begin{array}{l}\text { Type of data } \\
\text { source }\end{array}$ & $\begin{array}{c}\text { Duration } \\
\text { (Hours \& } \\
\text { minutes) }\end{array}$ & Kind of respondents & Remarks \\
\hline $\begin{array}{l}\text { Interviews } \\
\text { and field } \\
\text { notes }\end{array}$ & $2 \mathrm{hrs}$ & $\begin{array}{l}\mathrm{VTI}_{2} 1 \text { male administrator } \mathrm{AM}_{2} 2 \\
\text { male teachers; } \mathrm{TM}_{3} \& \mathrm{TM}_{4}\end{array}$ & $\begin{array}{l}\text { VTI }_{1} 7 \text { years collaborating } \\
\text { with MVP. } \\
\text { AM1 } 40 \text { years of practice } \\
\text { and teaching. Teachers: } \\
\text { less than } 15 \text { years of } \\
\text { experiences }\end{array}$ \\
\hline $\begin{array}{l}\text { Focus } \\
\text { group } \\
\text { interviews }\end{array}$ & 30 mins & $\begin{array}{l}3 \text { male students } \mathrm{SM}_{1} \text { of metal } \\
\text { fabrication from } \mathrm{VT}_{2}\end{array}$ & $\begin{array}{l}\text { Had participate in action } \\
\text { research project by MVP } \\
\mathrm{SF}_{2}\end{array}$ \\
\hline $\begin{array}{l}\text { Interviews } \\
\text { and field } \\
\text { notes }\end{array}$ & $55 \mathrm{mins}$ & $\begin{array}{l}\text { Workplaces: Organization } \mathrm{W}_{10} 0 \\
\text { Government, Qualification } \\
\text { standards, Assessment and } \\
\text { certification; } 1 \text { male } \mathrm{W}_{1} \mathrm{M}_{1} 0\end{array}$ & $\begin{array}{l}\text { Over } 7 \text { years collaboration } \\
\text { with MVP. } \\
\text { Over } 25 \text { years of work and } \\
\text { teaching }\end{array}$ \\
\hline $\begin{array}{l}\text { Interviews } \\
\text { and field } \\
\text { notes }\end{array}$ & 52 mins & $\begin{array}{l}\text { Organization } \mathrm{W}_{2} 0 \text { National } \\
\text { Assessment Board for VET } \\
\text { disciplines; } 1 \text { male } \mathrm{W}_{2} \mathrm{M}_{2} 0\end{array}$ & $\begin{array}{l}\text { Over } 7 \text { years collaboration } \\
\text { with MVP. } \\
19 \text { years of work and } \\
\text { former MVP student }\end{array}$ \\
\hline $\begin{array}{l}\text { Interviews } \\
\text { and field } \\
\text { notes }\end{array}$ & $40 \mathrm{mins}$ & $\begin{array}{l}\text { Industry } \mathrm{W}_{3} \mathrm{I} \text {; Large parastatal } \\
\text { dealing in sugar manufacturing } 1 \\
\text { male } \mathrm{W}_{3} \mathrm{MI}\end{array}$ & $\begin{array}{l}4 \text { years collaboration with } \\
\text { MVP. } \\
20 \text { years of practice and } 12 \\
\text { years as training officer }\end{array}$ \\
\hline
\end{tabular}

Key respondent categories (Cat): Cat 1: MVP project administrators, Cat 2: MVP students, mentors and action research supervisors. Cat 3: VTIs and workplace

The pretesting of the interview guides was done before the final data collection to ensure the reliability and consistency of data collection instruments, and the results were used to modify some aspects of the guides.

Multiple forms of evidence to corroborate data (Creswell \& Miller 2000) were employed to validate the findings. The interview data were backed-up with documentary evidence from the MVP project, including program documents, reports, collaborating stakeholders' meeting minutes, and students' theses. More so, the validating of respondents' responses, which entailed taking transcribed data back to the respondents to check them for quality and accuracy was done.

Through content analysis (Krippendorf, 2012; Cohen, Manion, \& Morrison, 2007), we summarised the texts based on pre-existing categories in the CHAT framework while 
subcategories emerged from the data. Data transcription was done a line by line, and excerpts for further analysis chosen based on how well they satisfy the category. The data were broken down into discrete parts through the open coding process. Through axial coding, we explored the coded, examined their interrelationships, and the codes and categories compared to existing theory. Following the CHAT, the data were organised into three main categories: identifying collaborative activities; mediating artefacts, rules, community and division of labour in implementing collaborative activities; and outcomes of the collaborative activities. Data analysis was mainly dependent on the theoretical proposition (Swanborn, 2010) provided in the CHAT (Engestrom, 1987; 2001). To address ethics issues, approval from the Norwegian Centre for Research and Data (NSD) and the Uganda National Council of Science and Technology (UNCST) was done. Permission from VTI and workplaces as well as consent from all the participants was sought and obtained.

\section{Findings}

The main questions in the study were: What collaborative activities are in the MVP study program that allows for learning between VTIs and workplaces and how is knowledge constructed amongst the participating actors? We will present the findings on both questions concurrently.

\section{Identifying Collaborative Activities}

The study respondents identified a range of views regarding collaborative activities that link MVP learning to workplaces and VTIs. Whereas the MVP mentors, students, and project administrators held similar views on this question, the responses by VTIs and workplaces respondents differed from those of MVP respondents. In the following excerpt, a junior female mentor (MJF2) reported about the collaborative activities:

I think the important thing is the issue of field expeditions [...]. To accomplish each course; students have to go outside into the world of work, conduct a oneday field expedition [...]. At times, we hold workshops here [...] about vocational action research [...] where we invited people from the world of work. We hold symposiums $[\ldots]$, and so far we have held two.

MJF2 identified several collaborative activities, including field expedition, symposiums, and workshops. Furthermore, a female MVP student (SF1) reported other collaborative activities 
in the program, such as action research projects, in which students deal with a challenge, try out actions until the problem is solved. In an interview with a male administrator (W3MI) from industry, he indicated that his organisation had correspondences with many institutions on several activities. However, he could not single out activities for the MVP program. Similarly, the administrator (AM1) from VTI1 revealed that one of his teachers engaged other staff in a training program, although he did not know the core details of what she was doing.

Responses by AM1 and W3MI reflect levels of participation and interaction in collaborative activities, although the respondents could not recall the exact activities that are for the MVP. We attribute limited knowledge regarding collaborative activities by some VTIs and workplaces to information gaps amongst the different activity systems. For the purposes of this paper, only two of the identified collaborative activities - field expeditions and action research projects - will be analysed due to their focus on promoting learning through collaboration.

\section{Mediating Artefacts Tools, Rules, Community, Division of Labour in Collaborative Activities}

\section{FIELD EXPEDITIONS}

The program document for the MVP (Kyambogo University, 2009, p.16) stipulates that each student will do a project in each course - either field expedition or mini research. One junior female mentor (MJF2) revealed that field expeditions are organised for one day as she reported: 'We conduct a one-day field expedition to find out how they [VTIs and workplaces] are doing work, and we [MVP] relate work requirements to how we teach and where there is a gap and see how we can bridge that gap.' An AR project supervisor (ASF1) and a senior mentor indicated that organising field expeditions begin with making contacts to prospective sites:

We identify possible collaborative workplaces and VTIs and write to them about the intentions of the visit. When they consent [...], we identify which days and times are convenient and then group the students to go. We strategically identify those places based on issues within the VET, for example, gender, information communication technology, and entrepreneurship. 
After identifying suitable sites, the preparation of artefact tools employed in executing field expeditions commences as a male MVP student (SM1) reported: 'we develop tools including questionnaires and interview guides that [...] guide the process of gathering information.' Regarding the division of labour in implementing field expeditions, a junior male mentor (MJM2) revealed the following:

Designing and developing the tools is done with the learners. [...] We do the facilitation for each field activity we intend to do and also participate in the plenary sessions where students give us feedback of what they got from the field.

On the aspect of conducting field expeditions, a male MVP student (MSM1) responded that 'We go to the sites, for instance, Kakiira sugar works, Jinja VTI, Lubona Bee farming, and Standard Signs Limited. After each visit, we transcribe, document findings and submit reports for assessment, and the mentors support us.'

MVP mentors and students reported several activities in implementing field expeditions, which included the following: facilitating different aspects for study; designing and developing data collection tools; selecting and contacting study sites; conducting field work; transcribing data; presenting findings; and reporting, writing and assessing. The field expedition process was aided by data collection tools and field reports, as the artefacts tools and tasks were executed collectively between the actors.

One of the challenges encountered in implementing field expeditions was on short duration. A female MVP student (SF1) revealed that 'they [MVP] planned field expedition poorly. Mentors informed us that we would spend two days — one per study site [...]. However, we did too many activities on one day and returned to the university.' The issue of short duration was echoed by the mentors, who suggested increasing the trip to two days to allow follow up on the findings.

\section{OUTCOMES OF THE FIELD EXPEDITIONS}

Field expeditions facilitated the learning of various components of the MVP program, which promoted learning through participation in real life situations. The project administrator (PAM1) stated the following:

If students are to understand research methods [...] they have to go out to the world of work, conduct inquiries through interviews, focus group discussions, 
and observations. Through engaging in conducting research, MVP students understand research methods.

Similarly, an administrator from VTI1 (AM1) observed that interactions on various issues can generate ideas that stimulate improvements in teaching.

This sentiment was echoed by an organisation officer (W2M2O), who indicated that interactions with MVP students during facilitation enabled him to reflect on his work practices before, during and after facilitation, which stimulated him to improve. Furthermore, a male junior mentor (MJM2) revealed that through participating in collaborative activities, he was able to understand issues related to teaching and workplace requirements. Also, a male respondent (W3M3O) from industry W3I commented that 'For us here [industry], we have experienced workers. So by allowing these people [VTIs] to come here to train and learn, it becomes a way of sharing experiences and identifying our future employees.'

Collaborative activities were multipurpose. They promoted learning through sharing experiences, stimulated improvements in teaching and work practices, and became an avenue for workplaces to identify future employees. The unveiled work patterns, practices, and experiences of the three activity systems complement one another in training a competent vocational teacher.

\section{ACtion Research Projects by MVP students}

MVP students are expected to undertake both mini and final thesis projects in the process of training (Kyambogo University, 2008; 2009). In an interview with a female project administrator (PAF1), she revealed that they organise four months AR projects in the final year of study where the MVP students solve problems encountered in their workplaces. However, a male project administrator (PAM1) indicated that 'AR activities required more time to get results'. He further revealed that 'we [MVP] are constrained by the university regulation where students have to finish their project within a given time frame which affects the quality of research done.'

The project administrators raised two problems with AR projects: short duration for implementing AR projects and the strict timeframes set by the university. Whereas the MVP students are expected to execute their AR projects within a stipulated timeframe set by the 
university, the workplaces and VTIs have their schedules, which may not match those of the university.

Turning to the organisation of the AR projects, a male AR supervisor (ASM1) reported that two approaches as explained below.

When MVP students go to their workplaces, they organise for [...] the work process analysis together with their participants. The work process analysis involves understanding the process of how they do their work. [...] they identify the areas in the work processes that have gaps. They prepare a future workshop in order to go in-depth to understand the area of concern $[\ldots]$ and suggest solutions to the problems.

ASM1 identified two artefact tools in conducting action research: work process analysis and future workshop. In the former, the actors in the projects engage in describing their work; they define the competencies needed to perform the work and identify the gaps. In the latter, the actors in the projects critically analyse the identified gaps in the work process and make suggestions about possible solutions. The female AR supervisor (ASF1) indicated that future workshop and work process analysis are tools employed in conducting situational analysis wherein actors in the projects analyse the strengths, weaknesses, opportunities about their work. Furthermore, she observed that participation in the AR projects was voluntary. Active participation was reported mostly for VTI teachers and students, not administrators. A female MVP student (SF1) asserted that 'I obtained full participation of all other staff except the administrators due to their busy schedules.' The administrator VTI2 (AM2) attributed his absence from some project meetings to conflicting schedules. He indicated that 'there is a challenge of overlapping of activities of the institution with those organised by MVP students.'

A male MVP student (SM1) also reported the absence of teachers and students from project activities which delayed the execution of project activities. He attributed the absence of teachers to the lack of incentives to motivate them to attend. He revealed that 'the attitude of the AR project participants was generally not good.' 
Student (SF1) registered a high rate of attendance for teachers and students as compared to administrators. Another student (SM1), though, registered low attendance amongst the actors. MVP students attributed the absence of the actors to the lack of incentives and conflicting work schedules. The absence of direct implementers and beneficiaries of AR projects slowed the implementation process of the initiated interventions, thus limiting the achievement of the intended objectives of collaborative activities.

Concerning the supervision of AR projects, the male AR supervisor (ASM1) indicated that the supervisors and mentors play a fundamental role in guiding students' projects. $\mathrm{He}$ revealed that 'supervisors need to be present during problem identification and when deciding interventions since students are not yet experts.' Regarding the sharing of roles between mentors and supervisors, a female junior mentor (MJF2) said that 'each student was assigned two supervisors and a supportive mentor to guide and support the research processes where both parties were intended to offer support collaboratively. However, this was not always the case.' MVP students observed that this uncoordinated mode of supervision yielded contradictory comments from mentors and supervisors about their work.

Mentors and AR project supervisors appreciated each other's role in supervising the projects, although the MVP students were dissatisfied with the isolated nature of supervision, which yielded contradictory comments about their work. One female AR project supervisor (ASF1) said that the outcome of AR project supervision was learning through doing:

As a supervisor, you are not the author of knowledge you are also learning [...] I would say, you do not dictate. You have to keep a dialogue with the students and also observe workplace participation to establish whether they are willing to change or not. You cannot supervise AR projects from a distance.

One supervisor (ASF1) emphasised learning through participation in the actual tasks and learning by communicating with other actors, which are the participatory approach significant for action-oriented projects.

The implementation of AR projects was hampered by several challenges, including organization dynamics. One MVP project administrator (PAM2) reported that 'some of the interventions needed resources which neither the researcher nor the organisation had. At times, the suggested interventions were not part of their [VTIs and workplaces] work plan.' 
The administrator (PAM2) identified organisational dynamics as a major constraint to the implementation of AR projects - a situation we attribute to cultural differences among the three activity systems resulting in each one setting different targets.

\section{OUTCOMES OF THE AR PROJECTS}

AR projects promoted learning by solving problems encountered in teaching and learning at the VTIs. One MVP student (SF1) indicated that VTI1 focused on examining the existing pedagogical approaches to enhance students' practical competence in the woodwork department. The intention was to provide students with more practical training and to curb the dropout of students from the carpentry and joinery course. In tackling the above issues, the actors at VTI1 provided more hands-on training; students made furniture and also conducted field visits and attended career guidance and counselling sessions. One student (SM3) testified that 'they organised a study tour to Kiwenda where we found many modern machines. They also brought an OB [old boy] engineer to talk to us about career progression.' An MVP student (SF1) indicated that the field visits to various industries were intended to expose the actors to current work practices as well as the materials being used. The outcome of this AR process included acquiring skills concerning designing and making furniture and using and maintaining machines. Field visits also exposed the actors to modern work practices and technology, which they could incorporate in their teaching, thus stimulating improvements.

However, the other MVP student (SM1) indicated that VTI2 focused on improvising training resources to enhance practical training in metal machine work in the fitting mechanics' department. However, VTI2 lacked practical training opportunities, as SM1 reported that 'the materials for training were not available to the students on time, and most teachers would only teach theoretically.' The student SM1 decided to use scrap materials, such as timber and plastic, to make seals and gears instead of using metal. The actors from VTI2 welcomed the ideas on improvisation. A teacher (TM3) stated that 'improvisation eliminates time wastage during teaching whereby; using recycled materials allowed for practical learning to progress.' An administrator (AM2) commended the student SM1 for his improvisation and recommended him for promotion to a higher teaching position. 
From the above findings, the outcomes from the AR project at VTI2 included the acquisition of creative skills through improvisation skills as well as planning skills, decision-making skills, and hands-on skills.

\section{Discussion}

Field expeditions and AR projects were identified as the principal collaborative activities incorporated in the MVP study program to support the back and forth learning between VTIs and workplaces. Field expeditions were organised to facilitate the learning of various components of the MVP program. Interactions within the field expeditions enabled the sharing of experiences; they also stimulated reflections which triggered improvement in teaching and work practices.

Indeed, engaging in field expeditions promoted learning through participation in objectoriented activities (Sannino, Daniels, \& Guteirrez, 2009).

Field interactions also revealed work patterns, practices, and experiences that could be incorporated by VTIs in training competent vocational teachers and, thus, bridging the skills gap.

The AR projects were conducted for four months by MVP students at their respective VTIs; where they focused on improving practical training. The VTI actors engaging in examining their existing teaching practices and working together to improve them characterises the notion of double bind suggested in expansive learning (Engestrom, 1987; 2016; Engestrom \& Sannino, 2010). Based on this notion, MVP students, together with the actors in the AR projects during situational analysis, reflected upon their teaching practices, identified the existing gaps, modelled and implemented action-oriented interventions in order to improve them. The actors adopted teaching strategies that encouraged learners to engage in hands-on training in designing and making items, which allowed for learning by participating in authentic work situations. The experiences and exposure to current work practices and modern technology resulting from field visits by VTIs were a basis to enrich and update the teaching content about workplace expectations. Through reflecting on their past teaching as well as by assimilating and adopting new teaching strategies, the actors expanded their learning spectrum (Engestrom, 1987; 2016). When adopted in teaching vocational teacher educators, these new skills will lead to both individual and organisational changes in work, teaching and learning processes. Such expansion leads to new activities, (Engestrom, 1987) 
which Engestrom (2016) and Engestrom and Sannino (2010) describe as a horizontal movement and a process of hybridization. However, introducing these new approaches into the existing teacher-centred, time-bound and examination-oriented curriculum produced tensions and contradictions.

VTIs suffered from insufficient training resources; therefore, they adopted teaching strategies that emphasised learner participation in knowledge generation, but this created tension because of the limited resources, and it became unsustainable.

Although Engestrom (2001) argues that participation in human activities; oriented towards objects is characterised by ambiguity and surprises, a shift from the teacher to learner-centred teaching strategies was expected to yield internal systemic contradictions. Thus, the actors, during the implementation of the collaborative activities had to resolve the cultural contradictions arising from changes in teaching practices. Therefore, we advocate for a systemic change in vocational teacher education in Uganda-from a teacher-centred approach to a learner-centred approach.

Implementing collaborative activities was hampered by several factors. These include the unharmonised work schedules for the three activity systems, the little time allotted to the activities, the rigid activity schedules, and the deviating target outcomes for the three systems. VTIs prioritised participation in collaborative activities since they promoted the sharing of experiences, exposure to new work practices, and the adoption of new teaching strategies. For workplaces, this was secondary to the production of goods and services, despite their ongoing expectation of receiving competent workers from the training institutions. The VTI and workplaces actors held different motives, priorities, and expectations concerning collaborative activities. The lack of guidelines for collaboration and poor coordination was responsible for the inconsistencies in understanding the object of collaborative activities by the actors. This finding corroborates Engestrom's (2005) view that contradictions within the activity systems accrue from weak instruments for collaboration. Rather than being a driving force for change as Engestrom $(2001 ; 2005)$ argues, the internal contradictions encountered in collaborative activities constrain their implementation.

Joint and active participation were exhibited mainly by VTI teachers and students in implementing collaborative activities, more so than administrators. Involving actors in all stages of the collaborative activities developed a sense of ownership and a shared responsibility in knowledge generation. The most affected actors in the AR projects were the 
teachers and students, which was a pull factor for their participation and was not experienced by the administrators. Obtaining the best results from the interventions required efforts by all of the actors. As Engestrom $(1987 ; 2016)$ and Engestrom and Sannino (2010) argue, modelling and developing new practices, require joint and collaborative efforts by all of the members within an activity system. Therefore, the limited participation by administrators weakened the implementation and sustainability of the initiated projects. Consequently, due to limited financial support, VTI2 implemented low-cost interventions. The lack of financial support by institute administrators could be resolved by involving all of the actors at all stages of implementing collaborative activities within and across the systems.

\section{Conclusion}

The study aimed at examining the current collaborative activities in the MVP program that allow for learning in VTIs and workplaces. Field expeditions and AR projects were the principal activities embedded within the MVP program to support back and forth learning in workplaces. Engaging in collaborative activities was an active and participatory process that allowed for learning from real and authentic workplace situations. The outcome of the collaborative activities was an improvement in teaching and work practices, which were reflected in the adoption of new strategies of learning as well as in designing and making items from improvised materials. Improved teaching and work practices in vocation teacher education are vital for bridging the skills gap and for producing competent VET graduates.

For successful implementation and sustainability of the collaborative learning activities in the MVP program, joint and active member participation is paramount. There is a need for clear guidelines on the objects and outcomes of collaborative activities for all actors involved in ensuring a coordinated and harmonised implementation process.

The collaborative activities enabled actors to learn by solving problematic situations in their work; by executing tasks and doing the associated activities. The actors attained research skills, teamwork skills, practical and creative skills. Through adopting learner-centred approaches in AR projects; actors were exposed to active and creative ways of teaching and learning, which improved their attitude towards learning, and motivated them to participate in collaborative activities. Introducing a learner-centred approach into a teacher-centred education system caused systemic tensions and contradictions, which affected the intended motives of the collaborative activities. There is a need to improve the current education 
system, which is predominantly teacher-centred, to allow learning strategies that focus on the learners and that help them decide, control and direct their learning.

\section{References}

Ankrah, S., \& Al-Tabbaa, O. (2015). Universities-industry collaboration: A systematic review. Scandinavia Journal of Management .Vol 31, 387-408. https://dx.doi.org/10.1016/j.scaman.2015.02.003

Ayonmike, C. (2016). Technical vocational education and training in Nigeria for job creation and wealth generation: Myths and realities. ATBU. Journal of Science, Technology \& Education (JOSTE), Vol. 4(2), 1-8. Retrieved from http://www.atbuftejoste.com/index.php/joste/article/view/197/pdf_150

Cacciattolo, K. (2015). Defining workplace learning. European Scientific Journal. Vol 1, 243-250. http://eujournal.org/index.php/esj/article/viewFile/5559/5354

Cohen, L., Manion, P., \& Morrison, K. (2007). Research methods in education, 6th edit. New York: Routledge.

Daniels, H., Edwards, A., Engestrom, Y., Gallagher, T., \& Ludvigsen, S. R. (2010). Activity Theory in Practice: Promoting learning across boundaries and agencies. New York: Routledge.

Davids, I. A.; Bossche, V. P.; Gijbels,D.; Garrido, F. M. (2017). The impact of individual, educational, and workplace factors on the transfer of school-based learning into the workplace. Vocations and Learning, 10, 275-306. DOI: https://dx.doi.org/10.1007/s12186-016-9168-1.

Engestom, Y. (2016). Studies in Expansive Learning: Learning what is not yet there. New York: Cambridge University Press.

Engestrom, Y. (1987). Learning by expanding: An activity-theoretical approach to developmental research. Helsinki: Orienta-Konsultit.

Engestrom, Y. (2001). Expansive learning at work: Towards an activity theoretical reconceptualization. Journal of Education and Work, 14:1, 133-156. https://dx.doi.org/10.1080/13639080020028747 
Engestrom, Y. (2005). Developmental Work Research: Expanding Activity theory in practice. Berlin: Lehmanns Media.

Engestrom, Y., \& Sannino, A. (2010). Studies of expansive learning: Foundations, findings and future challenges. Educational Research Review, 5(1), 1-24. DOI: https://dx.doi.org/10.1016/j.edurev.2009.12.002

Eraut, M. (2004). Informal learning in the workplaces. Studies in Continuing Education. 26 (2) 247-273 DOI: $\underline{\text { https://dx.doi.org/10.1080/158037042000225245 }}$

Fenwick. (2001). Tides of change:New themes and questions in workplace. New Directions for Adult and Continuing Education, Vol 92, 3-17. Retrieved from: http://web.b.ebscohost.com.ezproxy.hioa.no/ehost/pdfviewer/pdfviewer?vid=1\&sid=b $\underline{\text { 5e64b95-b3ab-465c-a501-8ce5fadab5cf\%40pdc-v-sessmgr03 }}$

Flynn, M. C.; Pillay, H.; Watters, J. (2016). Industry-school partnerships: boundary crossing to enable school to work transitions. Journal of Education and Work. 29:3, 309-331. DOI: $\underline{\text { https://dx.doi.org/10.1080/13639080.2014.934789 }}$

Hadidi, H., \& Kirby, D. (2017). University-Industry collaboration in a factor-driven economy: The perspective of Egyptian industry. Industry and Higher Education. Vol. 31(3), 195-203. DOI: https://dx.doi.org/10.1177/0950422217705243

Jonasson, C. (2014). Defining boundaries between school and work: teacher and students' attribution of quality to school-based vocational training. Journal of Education and Work, 27:5, 544-563. DOI: https://dx.doi.org/10.1080/13639080.2013.787483

Kalanda, E. (2012). Industrial Training a Workplace learning approach for Hotel trainees of Kyambogo University. Masters in Vocational Pedagogy Thesis: Kyambogo University.

Kato, H., \& Nsibambi, C. (2017). The potential of vocational pedagogy in vocational education and training part II. . International Journal of Vocational Education and Training. Vol 4(1), 93-106.

Krippendorf, K. (2012). Content Analysis: An Introduction to its Methodology. London: Sage.

Kvale, S., \& Brinkmann, S. (2015). Interviews: Learning the craft of qualitative research interviewing. 3rd edition. London: Sage Publication Ltd. 
Kyambogo University. (2009). Programme for Master's Degree in Vocational Pedagogy. Kampala: Harambee Publishing.

Kyambogo University. (2008). Handbook for Masters students in vocational pedagogy:

Equality complementary solidarity fidelity. Kampala: Harambee Publishing.

Kyambogo University. (2013). NORHED project document. kampala: Unpublished.

Lawrence, J., \& Tar, U. (2013). The use of grounded theory technique as a practical tool for qualitative data collection and analysis. The Electronic Journal of Business Research Methods. Vol. 11, 29-40. www.ejbrm.com/issue/download.html?idArticle=289

Lucas, B. (2014). Vocational pedagogy: What it is, why it matters and how to put it in practice. Report of the UNESCO-UNEVOC virtual conference. UNESCO-UNEVOC International Centre for Technical and Vocational Education and Training., 1-24. https://unevoc.unesco.org/fileadmin/up/eforum_synthesis_report_on_vocational_pedagogy.pdf

Mackenzie, R., \& Polvere, R. (2009). TVET Glossary: some key terms. In R. Maclean, \& D. Wilson, International handbook of education for the changing world of work: Bridging Academic and vocational learning. Vol 1 (pp. 59-76). Springer: UNESCOUNEVOC. Retrieved from https://link-springercom.ezproxy.hioa.no/chapter/10.1007\%2F978-1-4020-5281-1_4

Marsick, V., \& Watkins, K. (2015). Informal and incidental learning in the workplace. New York.: Routledge.

Mikkelsen, B. (2005). Methods for development work and research: A new guide for practitioners. Second edition. Thousand Oaks, London: Sage Publication.

Ministry of Education \& Sports. (2012). BTVET Strategic Plan 2012/13 to 2021/2. Skilling Uganda. Kampala: Ministry of Education and Sports. http://fenu.or.ug/wpcontent/uploads/2013/02/Skilling-Uganda-BTVET-Strategic-Plan-final-version.pdf

Ministry of Education Sports. (2014). Private sector contribution to the provision of relevant skills development in Uganda. Kampala: Commissioner, Private Schools and Institutions. Retrieved from: http://www.education.go.ug/files/downloads/Private\%20Sector\%20Contribution\%20t o\%20Skills\%20Development.pdf 
Mjelde, L. (2006). Magical Properties of Workshop learning. Studies in Vocational and Continuing Education . Bern: Peter Lang.

Mjelde, L. (2017). Learning through praxis and cooperation: Lev Vygotsky and vocational pedagogy. In F. Murhuenda-Fluixa, Vocational education beyond skill formation. (pp. 1-22). Bern: Peter Lang.

Mjelde, L., \& Daly, R. (2012). Aspects of vocational pedagogy as practice: Decolonizing minds and negotiating local knowledge. International Journal of Training Research, Vol. 10: 1, 43-57. DOI: https://dx.doi.org/10.5172/ijtr.2012.10.1.43

Mulcahy, D. (2011). Between work and learning: On pedagogic practice and interstitial space. Studies in Continuing Education. Vol. 33 (3), 203-217. DOI: https://dx.doi.org/10.1080/0158037X.2011.611495

Nisbet, G., Lincoln, M., Dunn, S.;. (2013). Informal interprofessional learning: an untapped opportunity for learning and change within the workplace. Journal of Interprofessional Care. 27(6), 469-475. DO1: https://doi.org/10.3109/13561820.2013.805735

Okello, B. (2009). A history of technical education in Uganda 1877-2005. Kampala.: Okello Benson.

Otaala, J., Maani, J., \& Bakaira, G. (2013). Effectiveness of university teacher education curriculum on the secondary school teacher performance in Uganda: The case of Kyambogo University. Journal of International Cooperation in Education, Vol 15 (3), 95-112. Retrieved from: https://home.hiroshima-u.ac.jp/cice/wpcontent/uploads/publications/15-3/15-3-06.pdf

Oyo, B. (2011). New perspectives of computing industrial training in Uganda. Gulu: Gulu University Printers.

Patton, M. (1990). Qualitative Evaluation and Research Methods. London: Sage Publication.

Patton, M. (2002). Qualitative research and evaluation methods, 3rd edition. London: Sage Publications, Inc.

Reid, A.-M. (2015). The role of the practice trainer as an agent of co-configuration. Vol.37, No.2. Studies in Continuing Education., 170-186. DOI: https://doi.org/10.1080/0158037X.2015.1028527 
Ridzwan, C. R.; Ruhizan, M. Y.; Dalilah, M. R.; Nazri, A. R. M.; Abu Bakar, M.; Zaliza, H.' Khairul, A. H. (2015). From training institution to workplace: Towards a training model in the industrial training institutes. International Education Studies; Vol.8, (2), 60-69. DOI: https://doi.org/10.5539/ies.v8n2p60

Ryan, M., Gwinner, K.; Mallan, K.; Livock, C. (2017). Preparing work-ready nurses: reflective learning for diverse students in the Australian vocational education and training sector. Studies in Continuing Education, 39:3, 268-285. DOI: https://doi.org/10.1080/0158037X.2017.1279136

Sannino, A., Daniels, H., \& Guteirrez, K. (2009). Learning and Expanding with Activity Theory. New York: Cambridge University Press.

Silverman, D. (2013). Doing qualitative research (4th ed.). London: Sage Publications Ltd.

Ssekamwa, J. (1997). History and development of education in Uganda. Kampala.: Fountain Publishers.

Swanborn, P. (2010). Case study research: What, why and how. London: Sage Publications Ltd.

Tavakol, M., \& Sandars, J. (2014). Quantitative and qualitative methods in medical education research: AMEE Guide No 90: Part II. Medical Teachers, 36, 838-848. DOI: https://doi.org/10.3109/0142159X.2014.915297

Uganda, G. (2008). The Business, Technical Vocational Education and Training (BTVET) Act. Kampala: Uganda Government.

Uganda. (2015). Second National Development Plan: Strengthening Uganda's Competitiveness for Sustainable Wealth Creation, Employment and Inclusive Growth. Kampala: Ugandan government. Retrieved from http://ngoforum.or.ug/wpcontent/uploads/downloads/2015/03/NDPII-Draft-3rd-March-2015-1pm.pdf

UNESCO. (2017). Global education monitoring report: Accountability in education. France: UNESCO Publishing Retrieved from https://www.skillsforemployment.org/KSP/en/Details/?dn=WCMSTEST4_193923

UNESCO-UNEVOC. (2012). Strengthening TVET teacher education. UNESCO-UNEVOC International Centre for Technical and Vocational Education and Training. (pp. 1-15). Bonn: UNESCO-UNEVOC. Retrieved from 
https://unevoc.unesco.org/fileadmin/user_upload/docs/Synthesis_report_eForumTVE $\underline{\text { T_Teachers.pdf }}$

Yin, K. R. (2014). Case study research: Design and methods. London: Sage Publications Ltd.

\section{Acknowledgment}

We thank the NORHED- MVP project for supporting and funding this study.

\section{Author biographies}

Dinavence Arinaitwe, $\mathrm{PhD}$ Candidate in Educational Sciences for Teacher Education, Faculty of Education and International Studies, Oslo Metropolitan University, Norway and Vocational and Technical Teacher Educator at Kyambogo University, Uganda. Her research areas are: Vocational Education and Training, Action Research and Vocational Pedagogy. PhD Arne Ronny Sannerud is Professor in Vocational Pedagogy at OsloMet - Oslo Metropolitan University - Department of Vocational Teacher Education. His research includes Vocational Education and Training, simulator training and action research. 